\title{
Effect of Probiotics on Oral Candidiasis: A Systematic Review and Meta-Analysis
}

\author{
Tiziana Mundula ${ }^{1}$, Federica Ricci ${ }^{2}$, Beatrice Barbetta ${ }^{3}$, Michela Baccini ${ }^{4, *,+}$ and \\ Amedeo Amedei $2,5, *,+$ (D) \\ 1 Unit of Biostatistics, Epidemiology and Public Health. University of Padova, 35131 Padova, Italy; \\ greentea@virgilio.it \\ 2 Department of Experimental and Clinical Medicine, University of Florence, 50134 Florence, Italy; \\ federica.ricci1987@gmail.com \\ 3 Department of Biostatistics, Rottapharm Biotech, 20900 Monza, Italy; \\ beatrice.barbetta@rottapharmbiotech.com \\ 4 Department of Statistics, Computer Science, Applications, University of Florence, 50134 Florence, Italy \\ 5 SOD of Interdisciplinary Internal Medicine, Azienda Ospedaliera Universitaria Careggi (AOUC), \\ 50134 Florence, Italy \\ * Correspondence: michela.baccini@unifi.it (M.B.); amedeo.amedei@unifi.it (A.A.) \\ + The last authors, Michela Baccini and Amedeo Amedei, contributed equally to the study.
}

Received: 6 September 2019; Accepted: 9 October 2019; Published: 14 October 2019

\begin{abstract}
Oral candidiasis (OC) is an increasing health problem due to the introduction of new drugs, population aging, and increasing prevalence of chronic illness. This study systematically reviews the effects of the oral intake of probiotics, prebiotics, and synbiotics on Candida spp. counts (colony-forming units $(\mathrm{CFU}) / \mathrm{mL}$ ) in oral and palatal samples. A literature search was conducted. Twelve studies, eight randomized clinical trials (RCTs), and four pre-post studies, resulted as eligible for the meta-analysis, which was performed through a Bayesian random-effects model. All studies analyzed probiotics, and none of them analyzed prebiotics or synbiotics. The treatments effects were measured in terms of odds ratio (OR) of OC $\left(\mathrm{CFU} / \mathrm{mL}>10^{2}, 10^{3}\right.$, or $\left.10^{4}\right)$. The meta-analytic OR was 0.71 (95\% credibility interval (CrI): 0.37, 1.32), indicating a beneficial effect of treatment; the $I^{2}$ index was $56.3 \%$. Focusing only on RCTs, the OR was larger and more precise at 0.53 (95\% CrI: $0.27,0.93$ ). The effect of treatment appeared to be larger on denture wearers. Our findings indicate that the intake of probiotics can have a beneficial effect on OC and that the effects could vary according to the patients' characteristics. Due to the presence of medium-high-risk studies, the results should be interpreted with caution.
\end{abstract}

Keywords: Candida spp.; oral candidiasis; Candida spp. treatment; Candida spp. prevention; Candida spp. carriage; probiotics; microbiota; Bayesian meta-analysis

\section{Introduction}

Candida spp. represent a commensal yeast belonging to the normal microbiota localized on the surface of different body sites (skin, oral cavity, and the gastro-intestinal, uro-genital, and respiratory tracts) of human beings [1]. Candida spp. colonization of the mucus membranes occurs very early in life, usually at birth [2]. Under specific conditions, the fungus can switch from a harmless form into a pathogenic form that can lead to infections [3]. About 75\% of healthy adults carry Candida spp. in the mouth; when there is a detection of a salivary Candida spp. count $>400$ colony-forming units (CFU) per mL, an infection occurs called "oral candidiasis" (OC) [4]. OC is predominantly caused by Candida albicans and by other species like Candida parapsilosis, Candida metapsilosis, Candida tropicalis, Candida khmerensis [5], Candida glabrata [6], and Candida dubliniensis [7]. Using a clinical evaluation, 
we can identify different Candida spp. infection phenotypes: pseudomembranous, erythematous, hyperplastic, angular cheilitis, median rhomboid glossitis [8,9], denture stomatitis [10], and linear gingival erythema [11]. All these conditions can determine a widespread spectrum of symptoms ranging from asymptomatic to very severe (such as burning sensation, pain, lesions, and bleeding), leading to discomfort in mastication, thereby limiting the food intake.

OC incidence is growing in the last few decades, because of the increase in some immune-correlated chronic illnesses (diabetes, cancer, human immunodeficiency virus (HIV)) and the intensive use of some drugs, such as antibiotics, chemotherapy, and immunosuppressants [12]. Some of major factors contributing to OC development are summarized in Table 1.

Table 1. Factors related to oral candidiasis (OC).

\begin{tabular}{l}
\hline \multicolumn{1}{c}{ Factors Related to Oral Candidiasis } \\
\hline Iatrogenic factors \\
Antineoplastic agents [12] \\
Broad-spectrum antibiotics [13] \\
Inhaled corticosteroids [14] \\
Substance abuse [15,16] \\
\hline Health conditions \\
Anemia [17] \\
Immunosuppression status [18] \\
Nutritional deficiencies [13] \\
Xerostomia [19] \\
\hline Diseases \\
Cancer [20] \\
Cushing syndrome [13] \\
Diabetes mellitus [21,22] \\
Human immunodeficiency virus (HIV) [23] \\
\hline Other factors \\
Age [17] \\
Denture wearing [20] \\
Pregnancy [24] \\
Smoke [16]
\end{tabular}

Sometimes, the superficial infection can spread out into the body, into the blood stream, causing deep and invasive candidiasis, which is associated with high hospitalization rate and even mortality [13]. The available pharmacological treatments (e.g., antifungal drugs) are very effective but present some critical points, such as frequent side effects and, in particular, antifungal resistance [1]. Therefore, it would appear critical to develop new prophylactic and complementary therapeutic strategies. The intake of probiotics seems a promising method in order to achieve these purposes. In fact, they can modulate the gut microbiota and its cross-talk with immune response, with local (intestinal) and systemic relapses [25-29].

Probiotics, that were identified and studied at the end of 19th century by various scientists such as Metchnikoff, Tissier, Grigorov, and Shirota, are defined as "live microorganisms that, when administered in adequate amount, confer health benefit to the host" [30]. The most used probiotics belong to Lactobacillus spp. and Bifidobacterium spp. and, to a lesser extent, to Saccharomyces spp., Bacillus spp., and Escherichia spp. [31]. The beneficial proprieties of probiotics are supported by various in vitro and in vivo studies, which used different bacterial strains (single or in combination), at different dosages [31,32]. Various studies proved the preventive and therapeutic effects of good bacteria, some of which involve metabolic functions such as fermentation of indigestible fibers [33], short-chain fatty-acid production [34], lactose tolerance [35], vitamin production [36], and reduction of cholesterol levels [37]. In addition, good bacteria have antimicrobial activity (such as competitive inhibition of pathogens [38]), produce bacteriocins [39], have antitoxin effects [40], and enhance the intestinal barrier function [41] (e.g., increased production of mucins, tight junction proteins, and goblet and Paneth cells [42]). Finally, commensal bacteria exercise immune modulation (such as the stimulation 
of immunoglobulin A (IgA) production, increased production of anti-inflammatory cytokines, and induction of regulatory T cells [42]).

These probiotics' proprieties suggested their use for the treatment and prevention of many medical conditions (diarrhea, constipation, inflammatory bowel disease, irritable bowel syndrome, allergic disease), sometimes with excellent results [31]. In addition, probiotics also showed an antifungal action and were successfully used in mucosal candidiasis, as reported in an in vivo study by Wagner in 1997 [43].

Sookkhee et al., in 2001, studied the effects on Candida albicans growth of different lactic-acid bacteria isolated from the oral cavity of volunteers and found that two strains, Lactobacillus paracasei and Lactobacillus rhamnosus, had the strongest effect on the yeast [44].

Lactobacillus reuteri is a promising bacterium (especially DSM 17938 and ATCC PTA 5289) for its anti-Candida properties, confirmed by several studies. In one of these, Lactobacillus reuteri was demonstrated to be able to reduce Candida load in vivo through co-aggregation, modification of oral $\mathrm{pH}$ with production of lactic acid and other organic acids that inhibit the virulence of Candida cells, and production of $\mathrm{H}_{2} \mathrm{O}_{2}$ [45].

In a recent in vitro study by Coman et al. (2014), the strains Lactobacillus rhamnosus IMC 501 and lactobacillus paracasei IMC 502, alone or in combination, showed an inhibitory effect on Candida spp. growth [46].

Lactobacillus delbrueckii ssp. bulgaricus B1 and Lactobacillus delbrueckii ssp. bulgaricus TAB2 were found to fight Candida, releasing high amounts of lactic acid [47].

Recently, it was found that Lactobacillus rhamnosus GR-1 and Lactobacillus reuteri RC-14 modulate Candida glabrata virulence, through the complete inhibition of fungal biofilms [48].

In addition, Lactobacillus acidophilus ATCC 4356 was found to inhibit the biofilm formation of fungus through in vitro experiments [49]. Biofilm formation is probably reduced through the production of substances called "bacteriocins" by probiotics. Wannun et al. reported the isolation of a bacteriocin, called "fermencin SD11", from Lactobacillus fermentum SD11, a human oral Lactobacillus, which has a strong inhibitory effect on oral Candida cells [50].

In 1997, Wagner et al. showed that the administration of probiotics could be a prophylactic and therapeutic strategy for mucosal candidiasis [43]. They demonstrated that the presence of four strains of bacteria (Lactobacillus acidophilus, Lactibacillus reuteri, Lactobacillus casei GG, and Bifidobacterium animalis) in the gastro-intestinal tract of immunodeficient mice reduced the number of Candida albicans cells, as well as the incidence and severity of mucosal and systemic candidiasis, prolonging their survival [43].

In a murine model, Matsubara et al. inoculated Candida albicans in the oral cavity and subsequently administrated an antifungal drug (nystatin) or probiotics (Lactobacillus acidophilus and Lactobacillus rhamnosus). At the end of the experiment, colonization by yeast cells was lower in the group that received probiotics (particularly L. rhamnosus) than in the group treated with nystatin [51].

In conclusion, even if the mechanism of probiotics' antifungal effect remains to be fully elucidated, some authors explored it in vitro and in vivo studies, showing that these bacteria may contrast Candida spp. infection through different and synergistic mechanisms of action.

In this paper, we performed a systematic review and meta-analysis of clinical studies, randomized controlled trials (RCT), and pre-post intervention studies, with the aim of investigating the efficacy of probiotics (compared with a control treatment or placebo) on oral Candida spp. counts in subjects of any age, sex, nationality, or health status.

\section{Systematic Review and Meta-Analysis}

\subsection{Materials and Methods}

\subsubsection{Literature Search}

The PRISMA statement guidelines were followed for conducting and reporting a systematic review and meta-analysis [52]. 
A computerized search of the articles published from inception to 1 February 2019, was conducted in Embase, Medline/PubMed, Cochrane Library central, clinicaltrials.gov databases, and other individual journals sources (Brazilian Dental Journal, Indian Journal of Health Sciences, and Biomedical Research Kleu), using the following search string: (candidosis OR candidiasis OR oral Candida spp. OR thrush OR yeast infection) AND (probiotic OR prebiotic OR yogurt OR synbiotic OR Lactobacillus OR Bifidobacteria OR Saccaromyces OR Bacillus OR xylitol). In the PubMed database, we activated the filter "Humans"; in Embase, we activated the filter "Research articles"; in Cochrane Library, we activated the filter "Trials"; and, in clinicaltrials.gov, we activated the filter "recruitment: terminated or completed". No restrictions of language, country, duration of follow-up, and participants' characteristics (race, age, and sex) were imposed.

\subsubsection{Study Selection}

Two authors independently reviewed titles and abstracts of the collected articles, applying pre-defined inclusion /exclusion criteria. The inclusion criteria were as follows:

(1) Randomized clinical trials or pre-post intervention studies;

(2) Availability of full text;

(3) Patients regardless of age, race, nationality, sex, and health status;

(4) Comparison between oral intake of probiotics, prebiotics, or synbiotics (of any type and dosage) with a control treatment or a placebo in RCT; and between pre- and post-treatment conditions in pre-post intervention studies;

(5) Outcome measurement expressed in $\mathrm{CFU} / \mathrm{mL}$ of oral Candida spp. counts in saliva or palatal samples.

The exclusion criteria were as follows:

(1) Studies with fewer than 10 participants;

(2) Reviews, articles, and case reports;

(3) Studies with incomplete outcome data;

(4) Studies reporting results in a format which was not suitable for a meta-analysis, for example, without Candida spp. counts/carriage.

\subsubsection{Data Extraction}

The same two authors performed the analysis of the full texts and the data extraction, with the intervention of a third author in the case of poor agreement or discrepancies. Each reviewer independently recorded data in a predefined data extraction form. The following data were obtained from each selected trial: first author name, year of publication, study design, availability of a registered study protocol, setting (institution, city, and country), characteristics of the studied population (mainly age and health status), sample size, number of total participants at the end of follow-up, number of subjects, number of subjects in the treatment and control groups (for RCTs), experimental treatment (strain type or mixture type, dose in $\mathrm{CFU} / \mathrm{mL}$, and frequency of administration), control treatment, inclusion and exclusion criteria, follow-up duration, characteristics of the sample, and outcome measure expressed in Candida spp. counts (in CFU/mL).

\subsubsection{Outcome Assessment}

For each selected study, we calculated the odds ratio of OC (Candida spp. counts lower than a threshold of $10^{2}, 10^{3}$, or $10^{4}$ ) of treated subjects versus controls, as a measure of treatment effect.

For seven RCTs (Hatakka et al. 2007 [52]; Ishikawa et al. 2015 [53]; Keller et al. 2018 [54]; Kraft-Bodi et al. 2015 [55]; Li et al. 2014 [56]; Myazima et al. 2017 [57]; Petti et al. 2001 [58]), it was possible to calculate the OR and its standard error from the $2 \times 2$ contingency table of the trial results. For the RCT by Burton et al. 2013 [59], which reported a continuous outcome (mean of Candida spp. counts in $\mathrm{CFU} / \mathrm{mL}$ ), we firstly calculated the standardized mean difference (SMD) between the treatment group 
and the control group; then, we derived the OR and the corresponding standard error according to the Hasselblad and Hedges method [60]. The same approach was also used for two pre-post studies (Rane et al. 2018 [61]; Sutula et al. 2013 [62]). In these cases, we assumed independence between pre and post means, thus overestimating the standard errors.

Rane et al. (2008) [61] reported the results of separated analyses conducted on three different samples of different age (50-59, 60-69, $\geq 70$ years). A fixed-effects meta-analysis was performed on the three results in order to obtain an overall combined estimate and the corresponding standard error.

Miyazima et al. (2017) [57] conducted an RCT with three treatment arms (placebo, treatment 1 with Lactobacillus acidophilus, and treatment 2 with Lactobacillus rhamnosus). We collapsed the results for the two experimental treatments in order to obtain an overall OR of treatment vs. placebo.

For the pre-post studies by Lopez-Jornet et al. 2018 [63] and Mendonca et al. 2012 [64], which reported the status of the patient in binary form, the McNemar OR was calculated [65].

\subsubsection{Risk of Bias}

The assessment of quality of the randomized clinical trials was performed using Review Manager 5.3 software, according to the Cochrane Handbook guidelines [66].

The two reviewers expressed, for each of the eight selected RCTs, their independent judgment (low risk, high risk, or unclear) on the following domains: random sequence generation, allocation concealment, blinding of participants and personnel, blinding of outcome assessment, incomplete outcome data, selective reporting, and other bias.

The assessment of quality of the pre-post intervention studies was performed using the quality assessment tool for pre-post studies with no control group developed by the United States (US) National Heart, Lung, and Blood Institute (NHLBI) [67].

In the case of disagreement between the two authors, a third investigator was involved to resolve the controversy.

\subsubsection{Statistical Analysis}

A Bayesian random-effects meta-analysis model was specified to combine the results of the selected studies and, successively, to combine the results from the subset of the RCTs [68]. Let $b_{i}$ be the estimate of the $\log (\mathrm{OR})$ from the $i$ th study, and $s_{i}$ be the estimate of the corresponding standard error $(i=1,2, \ldots, n)$. The random-effects meta-analysis assumes that the study-specific effects $b_{i}$ are mutually independent and follow the following model:

$$
b_{i}=\beta+u_{i}+\varepsilon_{i}, \quad u_{i} \sim N\left(0, \tau^{2}\right), \quad \varepsilon_{i} \sim N\left(0, s_{i}^{2}\right),
$$

where $\beta$ is the overall meta-analytic effect, $i$ is a random effect normally distributed with variance $\tau^{2}$, and $\varepsilon_{i}$ is an error term with known variance; $u_{i}$ and $\varepsilon_{i}$ are assumed to be independent. The meta-analysis model accounts for possible heterogeneity among studies through the random terms $u_{i}$, and the variance $\tau^{2}$ expresses the heterogeneity among studies. In the Bayesian formulation of the model, we need to specify prior distributions. Two non-informative priors were specified on the hyperparameters $\beta$ and $\tau^{2}$.

We used MCMC methods to obtain a sample from the joint posterior distribution of the parameters [69]. The posterior distribution of $\beta$ was summarized in terms of mean and $95 \%$ credibility interval (CrI), i.e., the 2.5th and 97.5 th percentiles of the posterior distribution. The posterior distribution of the $I^{2}$ index, which expresses the percentage of total variance captured by $\tau^{2}$, was summarized in terms of median and $95 \%$ CrI.

Sensitivity analyses were performed to evaluate the discrepancy between the results of the meta-analysis on the RCTs and the results obtained excluding the two RCTs that enrolled only subjects wearing dentures and the RCT that enrolled children. 
When the meta-analysis included fewer than three studies, a fixed-effects models was adopted where only the within-study component of the variance was accounted for.

The presence of publication bias was evaluated by inspecting a funnel plot [70,71] and calculating the Begg's test [72]. All analyses were performed with R software (v3.5.1) [73] and the library OpenBUGS (v3.0.7) [74].

\subsection{Results}

\section{Study Selection}

The initial search identified 2490 articles.

In total, 87 studies were excluded for duplication. Of the remaining 2403 papers, 2385 were excluded after the screening for title and abstracts because they did not fulfil the inclusion criteria.

Among the 18 remained eligible articles, four were eliminated because the full text was not available, the outcome was inappropriate, or the results were not reported. Finally, 12 studies were included in the meta-analysis.

Figure 1 illustrates the selection process, according to the PRISMA statement 2009.

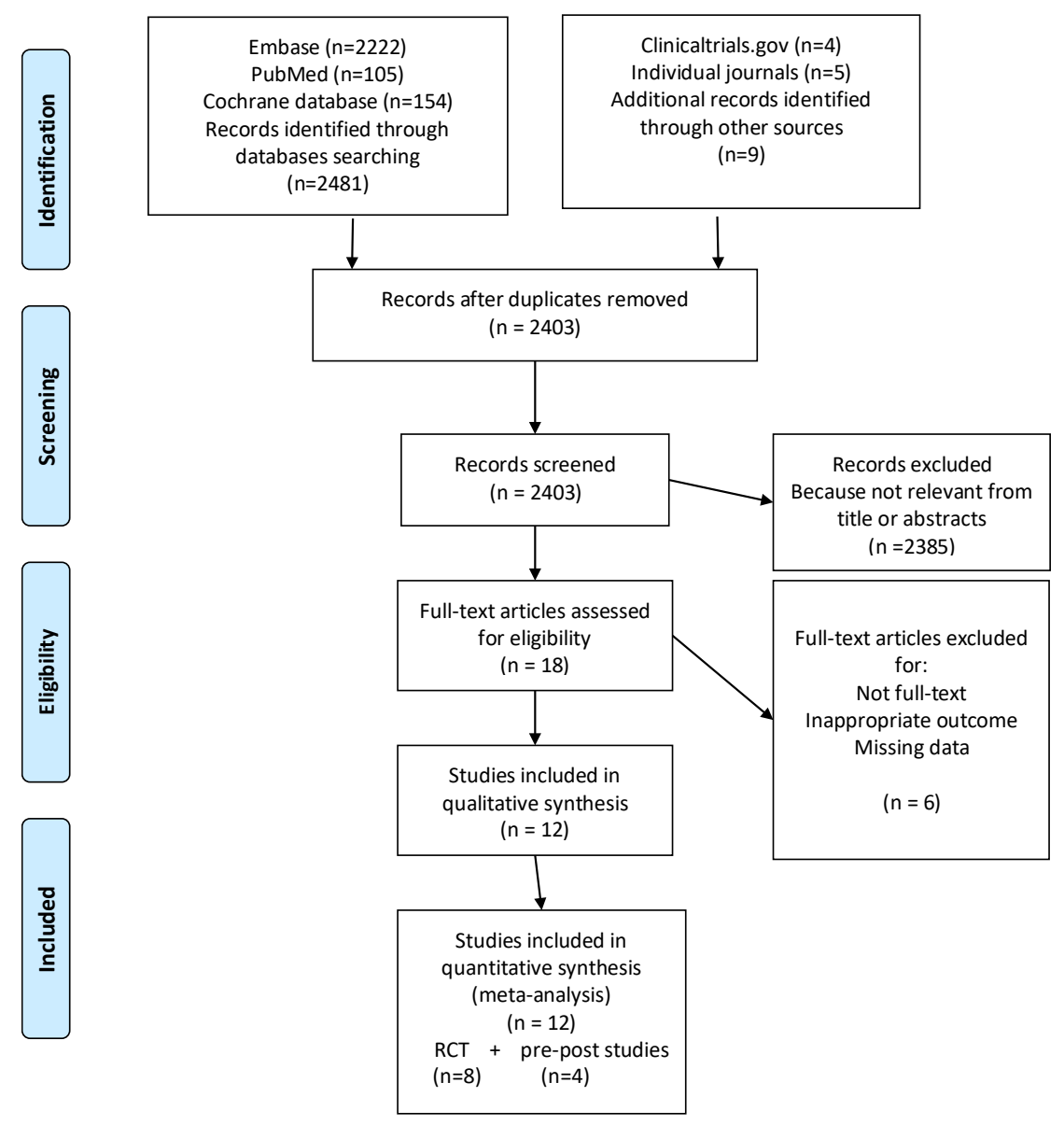

Figure 1. PRISMA flow diagram.

\subsection{Characteristics of the Included Studies}

An overview of the included studies is reported in Table 2, which includes the reference, study design, setting, enrolled population, number of participants, intervention, comparison, follow-up, sample type, and outcome measurement. 
Table 2. Overview of the included studies. RCT—randomized controlled trial; CFU—colony-forming unit; OR—odds ratio; CI—confidence interval.

\begin{tabular}{|c|c|c|c|c|c|c|c|c|c|}
\hline Reference & Study Design & Setting & Studied Population & No. of Participants & Intervention & Comparison & Follow-up & Sample Type & Outcome \\
\hline $\begin{array}{l}\text { Burton et al. } \\
2013 \text { [60] }\end{array}$ & RCT & $\begin{array}{l}\text { Schools with dental } \\
\text { clinics City: Dunedin } \\
\text { Country: New Zealand }\end{array}$ & $\begin{array}{c}\text { Child population, } \\
\text { schoolchildren with } \\
\text { active caries. Age: } 5 \\
\text { to } 10 \text { years (mean } 8.5 \\
\text { years) }\end{array}$ & $\begin{array}{l}\text { Total: } 83 ; 40 \text { in the } \\
\text { probiotic group, } 43 \\
\text { in the placebo } \\
\text { group }\end{array}$ & $\begin{array}{l}\text { Two lozenges with S. salivarius (each } \\
\text { lozenge } 3.6 \times 10^{9} \mathrm{CFU} \text { of strain), two } \\
\text { times a day, one in the morning and } \\
\text { one at night, for three months }\end{array}$ & $\begin{array}{l}\text { Placebo. Lozenges } \\
\text { with identical } \\
\text { appearance and } \\
\text { taste, without } \\
\text { probiotics }\end{array}$ & 3 months & $\begin{array}{l}\text { Saliva } \\
\text { samples }\end{array}$ & $\begin{array}{c}\mathrm{OR}^{*} 1.42795 \% \mathrm{CI} \\
\quad(0.667-3.054)\end{array}$ \\
\hline $\begin{array}{l}\text { Hatakka et al. } \\
2007[53]\end{array}$ & RCT & $\begin{array}{l}\text { Homes and sheltered } \\
\text { housing units City: } \\
\text { Helsinki Country: } \\
\text { Finland }\end{array}$ & $\begin{array}{l}\text { Elderly people, aged } \\
70-100 \text { years }\end{array}$ & $\begin{array}{l}\text { Total: } 192 ; 92 \text { in the } \\
\text { probiotic group, } 100 \\
\text { in the placebo } \\
\text { group. }\end{array}$ & $\begin{array}{c}\text { Daily } 50 \mathrm{~g} \text { of Emmental-type } \\
\text { probiotic cheese divided into two } \\
\text { portions, with Lactococcus lactis and } \\
\text { Lactobacillus helveticus as starter } \\
\text { cultures and } 10^{7} \text { CFU/g of each } \\
\text { probiotic strain: L. rhamnosus GG } \\
\text { (ATCC 53103), L. rhamnosus LC705, } \\
\text { and Propionibacterium freudenreichii } \\
\text { ssp. shermanii JS }\end{array}$ & $\begin{array}{l}\text { Daily } 50 \mathrm{~g} \text { of edam } \\
\text { type cheese, } \\
\text { divided into two } \\
\text { portions, with } \\
\text { Lactococcus lactis as } \\
\text { starter culture } \\
\text { without the } \\
\text { addition of other } \\
\text { probiotic strains }\end{array}$ & 16 weeks & $\begin{array}{l}\text { Saliva } \\
\text { samples }\end{array}$ & $\begin{array}{l}\text { OR } 0.50595 \% \mathrm{CI} \\
(0.263-0.970) \mathrm{OR} \\
\text { calculated for a } \\
\text { cut-off of Candida } \\
\geq 10^{4} \mathrm{CFU} / \mathrm{ml}\end{array}$ \\
\hline $\begin{array}{l}\text { Ishikawa et al. } \\
2015[54]\end{array}$ & RCT & $\begin{array}{l}\text { Patients seeking dental } \\
\text { treatment (complete } \\
\text { denture) at the School } \\
\text { of Dentistry, University } \\
\text { of São Paulo City: São } \\
\text { Paulo Country: Brazil }\end{array}$ & $\begin{array}{l}\text { Denture wearers } \\
\text { harboring Candida } \\
\text { spp. in the oral cavity } \\
\text { with no clinical } \\
\text { symptoms, aged } \\
\text { (mean) } 61.8 \pm 8.5 \\
\text { years }\end{array}$ & $\begin{array}{l}\text { Total: } 55.30 \text { in the } \\
\text { probiotic group. } 25 \\
\text { in the placebo } \\
\text { group }\end{array}$ & $\begin{array}{l}1 \text { capsule/day containing lyophilized } \\
\text { cultures (obtainedfrom } \\
\text { HardiStrain } ß-\text { Probiotics) of } L . \\
\text { rhamnosus HS111, L. acidophilus } \\
\text { HS101, and Bifidobacterium bifidum } \\
\text { combined in equal amounts, } \\
\text { reaching } 108 \mathrm{CFU}\left(3.3 \times 10^{7} \mathrm{CFU} \text { of }\right. \\
\text { each) per capsule }\end{array}$ & $\begin{array}{c}\text { Placebo } 1 \\
\text { capsule/day with } \\
\text { same characteristics } \\
\text { as the probiotic } \\
\text { product, but } \\
\text { without the } \\
\text { probiotic bacteria }\end{array}$ & 5 weeks & $\begin{array}{l}\text { Palatal } \\
\text { mucosal } \\
\text { samples }\end{array}$ & $\begin{array}{l}\text { OR } 0.06695 \% \mathrm{CI} \\
(0.013-0.338) \mathrm{OR} \\
\text { calculated for a } \\
\text { cut-off of Candida } \\
\geq 10^{4} \mathrm{CFU} / \mathrm{ml}\end{array}$ \\
\hline $\begin{array}{l}\text { Keller et al. } \\
2018 \text { [55] }\end{array}$ & RCT & $\begin{array}{l}\text { Clinic for oral medicine } \\
\text { City: Copenhagen } \\
\text { Country: Denmark }\end{array}$ & $\begin{array}{l}\text { Patients attending the } \\
\text { Clinic for Oral } \\
\text { Medicine, aged } \\
\text { median (67) years, } \\
\text { with diagnosis of oral } \\
\text { lichen planus }\end{array}$ & $\begin{array}{l}\text { Total: } 22.9 \text { in the } \\
\text { probiotic group, } 13 \\
\text { in the placebo } \\
\text { group }\end{array}$ & $\begin{array}{l}\text { Pre-treatment: all patients were } \\
\text { treated with the current } \\
\text { conventional treatment regimens at } \\
\text { the Clinic for Oral Medicine, } \\
\text { including those who required } \\
\text { additional conventional treatment } \\
\text { during the 1-year study period } \\
\text { Patients diagnosed with oral } \\
\text { candidiasis were treated } \\
\text { withnystatin, patients without oral } \\
\text { candidiasis were treated with } \\
\text { steroid, fluocinolone acetonide gel } \\
\text { 0.025\% Treatment: probiotic } \\
\text { lozenges containing two strains of } \\
\text { the probiotic bacteria L. reuteri (DSM } \\
17938 \text { and ATCC PTA 5289) } \\
\text { dissolved intra-orally three times } \\
\text { daily (morning, noon, and evening } \\
\text { just before bedtime) for } 16 \text { weeks }\end{array}$ & $\begin{array}{l}\text { Pre-treatment: the } \\
\text { same of } \\
\text { intervention group } \\
\text { Treatment: placebo } \\
\text { lozenges without } \\
\text { probiotic bacteria }\end{array}$ & 16 weeks & $\begin{array}{l}\text { Saliva } \\
\text { samples }\end{array}$ & $\begin{array}{l}\text { OR } 0.95295 \% \text { CI } \\
(0.125-7.275) \text { OR } \\
\text { calculated with } \\
\text { cut-off Candida } \\
\text { carriage yes/no }\end{array}$ \\
\hline
\end{tabular}


Table 2. Cont

\begin{tabular}{|c|c|c|c|c|c|c|c|c|c|}
\hline Reference & Study Design & Setting & Studied Population & No. of Participants & Intervention & Comparison & Follow-up & Sample Type & Outcome \\
\hline $\begin{array}{l}\text { Kraft- Bodi et } \\
\text { al. } 2015 \text { [56] }\end{array}$ & RCT & $\begin{array}{l}\text { Nursing homes. } \\
\text { Country: south of } \\
\text { Sweden }\end{array}$ & $\begin{array}{l}\text { Elderly people, aged } \\
\text { (mean) } 88 \text { years }\end{array}$ & $\begin{array}{l}\text { Total: } 174 ; 84 \text { in the } \\
\text { probiotic group, } 90 \\
\text { in the placebo } \\
\text { group }\end{array}$ & $\begin{array}{l}2 \text { lozenges daily the morning and in } \\
\text { the early evening, containing a } \\
\text { minimum of } 10^{8} \text { live bacteria of each } \\
\text { strain of the probiotic bacterium } \\
\text { Lactobacillus reuteri (DSM } 17938 \text { and } \\
\text { ATCC PTA 5289; Prodentis } \\
\text { Biogaia@AB, Lund, Sweden) }\end{array}$ & $\begin{array}{c}\text { Placebo lozenges } \\
\text { without active } \\
\text { bacteria }\end{array}$ & 12 weeks & $\begin{array}{c}\text { Saliva } \\
\text { samples }\end{array}$ & $\begin{array}{c}\text { OR } 0.50595 \% \mathrm{CI} \\
\text { (0.259-0.984)OR } \\
\text { calculated for a } \\
\text { cut-off of Candid. } \\
\geq 10^{4} \mathrm{CFU} / \mathrm{ml}\end{array}$ \\
\hline $\begin{array}{l}\text { Li et al. } 2014 \\
\quad[57]\end{array}$ & RCT & $\begin{array}{c}\text { Department of Oral } \\
\text { Medicine, West China } \\
\text { College of Stomatology, } \\
\text { Sichuan University } \\
\text { City: Sichuan Country: } \\
\text { China }\end{array}$ & 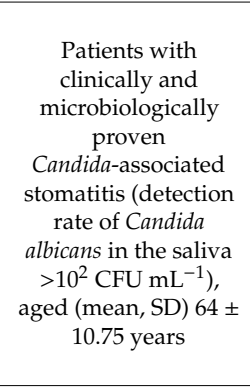 & $\begin{array}{l}\text { Total: } 65 ; 34 \text { in the } \\
\text { probiotic group, } 31 \\
\text { in the control group }\end{array}$ & $\begin{array}{l}\text { Pre-treatment: administration orally } \\
\text { of } 2 \% \text { sodium bicarbonate solution } \\
\text { and then application of } 2 \% \text { nystatin } \\
\text { pasteTreatment: four lozenges } \\
\text { containing the mixture of } B \text {. longum } \\
\left(5 \times 10^{6} \mathrm{CFU} \text { in } 0.5 \mathrm{~g} \text { of skim milk }\right. \\
\text { powder per tablet), } \mathrm{L} \text {. bulgaricus ( } 5 \times \\
10^{5} \mathrm{CFU} \text { in } 0.5 \mathrm{~g} \text { of skim milk } \\
\text { powder per tablet), and } S . \\
\text { thermophilus }\left(5 \times 10^{5} \mathrm{CFU} \text { in } 0.5 \mathrm{~g} \text { of }\right. \\
\text { skim milk powder per tablet)The } \\
\text { medication was applied three times } \\
\text { daily for } 4 \text { weeks. }\end{array}$ & $\begin{array}{l}2 \% \text { sodium } \\
\text { bicarbonate } \\
\text { solution and } 2 \% \\
\text { nystatin paste }\end{array}$ & 4 weeks & $\begin{array}{c}\text { Saliva } \\
\text { samples }\end{array}$ & $\begin{array}{l}\text { OR } 0.17695 \% \mathrm{CI} \\
(0.044-0.710) \mathrm{OR} \\
\text { calculated for a } \\
\text { cut-off of Candida } \\
\geq 10^{2} \mathrm{CFU} / \mathrm{mL}\end{array}$ \\
\hline $\begin{array}{l}\text { Lopez-Jornet } \\
\text { et al. 2018 [64] }\end{array}$ & $\begin{array}{l}\text { Before-after } \\
\text { study }\end{array}$ & $\begin{array}{l}\text { Clinica Odontologica } \\
\text { Universitaria Hospital } \\
\text { Morales MeseguerCity: } \\
\text { Murcia. Country: Spain }\end{array}$ & $\begin{array}{l}\text { Patients, aged (mean) } \\
71.2 \text { years }\end{array}$ & Total: 27 & $\begin{array}{c}\text { Lactobacillus reuteri DSM } 17938 \\
\text { (German Culture Collection of } \\
\text { Microorganisms) and ATCC PTA } \\
5289 \text { (American Type Culture } \\
\text { Collection) (GUM Periobalance }(\text {, } \\
\text { Sunstar) one tablet per day for } 28 \\
\text { days }\end{array}$ & & 28 days & $\begin{array}{c}\text { Saliva } \\
\text { samples }\end{array}$ & $\begin{array}{c}\text { OR } 3.00095 \% \mathrm{CI} \\
(0.312-28.842) \mathrm{OR} \\
\text { calculated with a } \\
\text { cut-off of Candida } \\
>10^{2} \mathrm{CFU} / \mathrm{mL}\end{array}$ \\
\hline $\begin{array}{l}\text { Mendonça } \\
\text { et al. } 2012 \text { [65] }\end{array}$ & $\begin{array}{l}\text { Before-after } \\
\text { study }\end{array}$ & $\begin{array}{c}\text { City: Taubaté Country: } \\
\text { Brazil }\end{array}$ & $\begin{array}{c}\text { Healthy women aged } \\
65 \text { or older who lived } \\
\text { in the city of Taubaté, } \\
\text { SP, Brazil }\end{array}$ & Total: 42 & $\begin{array}{l}1 \mathrm{~g} \text { (content of } 1 \text { envelope) of the } \\
\text { probiotic Yakult } \mathrm{LB}(\text { (Lactobacillus } \\
\text { casei and Bifidobacterium breve, } 2 \times \\
10^{7} \text { to } 10^{9} \text { and } 5 \times 10^{7} \text { to } 10^{9} \\
\mathrm{CFU} / \mathrm{mL} \text {, respectively), } 3 \text { times a } \\
\text { week, at the same hour, for } 30 \text { days }\end{array}$ & & 30 days & $\begin{array}{c}\text { Saliva } \\
\text { samples }\end{array}$ & $\begin{array}{l}\text { OR } 0.40095 \% \mathrm{CI} \\
(0.078-2.062) \mathrm{OR} \\
\text { calculated with a } \\
\text { cut-off Candida } \\
\text { carriage yes/no }\end{array}$ \\
\hline $\begin{array}{l}\text { Miyazima } \\
\text { et al. } 2017[58]\end{array}$ & RCT & $\begin{array}{l}\text { School of Dentistry, } \\
\text { University of São Paulo } \\
\text { City: São Paulo } \\
\text { Country: Brazil }\end{array}$ & $\begin{array}{l}\text { Denture-wearing } \\
\text { patients seeking for } \\
\text { dental treatment } \\
\text { (complete denture), } \\
\text { aged (mean, SD) } 64.4 \\
\pm 12.07 \text { years }\end{array}$ & $\begin{array}{l}\text { Total: } 60 ; 20 \text { in each } \\
\text { group (treatment } 1 \text {, } \\
\text { treatment } 2 \text {, control) }\end{array}$ & $\begin{array}{c}\text { Treatment } 1, \mathrm{~T} 1 \text { group: fresh cheese } \\
\text { added with probiotics containing } 8 \\
\text { to } 9 \log \text { CFU. }{ }^{-1} \text { of L. acidophilus } \\
\text { NCFMTreatment 2, T2 group: fresh } \\
\text { cheese added with probiotics } \\
\text { containing } 8 \text { to } 9 \log \text { CFU } \cdot \mathrm{g}^{-1} \text { of } L \text {. } \\
\text { rhamnosus } \mathrm{Lr}-32\end{array}$ & $\begin{array}{l}\text { PlaceboControl } \\
\text { group (C group): } \\
\text { fresh cheese with } \\
\text { no added probiotics }\end{array}$ & 8 weeks & $\begin{array}{l}\text { Mouth-rinse } \\
\text { samples }\end{array}$ & $\begin{array}{c}\text { OR } 0.46495 \% \mathrm{CI} \\
(0.155-1.392) \mathrm{OR} \\
\text { calculated for a } \\
\text { cut-off of Candida } \\
\geq 10^{3} \mathrm{CFU} / \mathrm{mL}\end{array}$ \\
\hline
\end{tabular}


Table 2. Cont.

\begin{tabular}{|c|c|c|c|c|c|c|c|c|c|}
\hline Reference & Study Design & Setting & Studied Population & No. of Participants & Intervention & Comparison & Follow-up & Sample Type & Outcome \\
\hline $\begin{array}{l}\text { Petti et al. } \\
2001 \text { [59] }\end{array}$ & RCT & Country: Italy & $\begin{array}{c}\text { Adult volunteers, } \\
\text { aged (mean) } 28.2 \\
\text { years }\end{array}$ & $\begin{array}{l}\text { Total: } 42 ; 20 \text { in the } \\
\text { yoghurt group, } \\
22 \text { in the control } \\
\text { group }\end{array}$ & $\begin{array}{l}125 \mathrm{~g} \text { of fruit yoghurt twice daily, } \\
\text { between breakfast and lunch, and } \\
\text { between lunch and dinnerThen, } \\
2 \text { weeks without yogurt intake }\end{array}$ & $\begin{array}{l}125 \mathrm{~g} \text { of fruit } \\
\text { soybean ice cream } \\
\text { twice daily, } \\
\text { between breakfast } \\
\text { and lunch, and } \\
\text { between lunch and } \\
\text { dinner Then, } \\
2 \text { weeks without } \\
\text { soybean ice cream } \\
\text { intake }\end{array}$ & 16 weeks & $\begin{array}{c}\text { Saliva } \\
\text { samples }\end{array}$ & $\begin{array}{l}\text { OR } 1.16795 \% \text { CI } \\
\text { (0.335-4.060)OR } \\
\text { calculated for a } \\
\text { cut-off of Candida } \\
\text { between } 3.5 \text { and } 7.6 \\
\times 10^{2} \mathrm{CFU} / \mathrm{mL}\end{array}$ \\
\hline $\begin{array}{l}\text { Rane et al. } \\
2018 \text { [62] }\end{array}$ & $\begin{array}{l}\text { Before-after } \\
\text { study }\end{array}$ & Country: India & $\begin{array}{l}\text { Healthy complete } \\
\text { denture wearers, } \\
\text { aged } \geq 50 \text { years }\end{array}$ & $\begin{array}{c}\text { Total: 60; } 20 \text { in } \\
\text { group A (age 50-59 } \\
\text { years), } 20 \text { in group } \\
\text { B (age 60-69 years), } \\
20 \text { in group C (age } \\
\geq 70 \text { years) }\end{array}$ & $\begin{array}{c}\text { Once daily, } 1 \text { capsule content of } \\
\text { probiotic (Probiotic immune®, } \\
\text { Zenith nutrition) in the palatal } \\
\text { region of the cleaned maxillary } \\
\text { denture }\end{array}$ & & 5 weeks & $\begin{array}{l}\text { Palatal } \\
\text { mucosa } \\
\text { samples }\end{array}$ & $\begin{array}{c}\text { OR* group A } 0.891_{95 \% \text { CI }} \\
\text { (0.290-2.736)OR } \\
\text { group B 1.323 95\% } \\
\text { CI (0.431-4.063)OR } \\
\text { group C } 0.84695 \% \\
\text { CI }(0.276-2.598)\end{array}$ \\
\hline $\begin{array}{l}\text { Sutula et al. } \\
2013 \text { [63] }\end{array}$ & $\begin{array}{l}\text { Before-after } \\
\text { study }\end{array}$ & $\begin{array}{c}\text { Manchester } \\
\text { Metropolitan } \\
\text { University City: } \\
\text { Manchester. Country: } \\
\text { United Kingdom }\end{array}$ & $\begin{array}{c}\text { Healthy dentate } \\
\text { volunteers, aged } \\
\text { (mean, SD) } 32 \pm 11.5 \\
\text { years }\end{array}$ & Total: 21 & $\begin{array}{l}\text { One bottle per day of drink milk } \\
\text { Yakult } \AA \text {, containing a minimum of } \\
6.5 \times 10^{9} \text { viable cells of probiotic } \\
\text { L. casei strain Shirota, for } 4 \text { weeks }\end{array}$ & & 4 weeks & $\begin{array}{c}\text { Saliva } \\
\text { samples }\end{array}$ & $\begin{array}{c}\mathrm{OR}^{*} 4.96795 \% \mathrm{CI} \\
(1.662-14.843)\end{array}$ \\
\hline
\end{tabular}

* OR derived from the standardized mean difference (SMD) between the treatment and the control group, according to the Hasselblad and Hedges method [60]. 
The 12 papers included in the analysis were published from 2001 to 2018. Eight studies were RCTs [53-60], and four were pre-post intervention studies [62-65].

The sample size ranged from 21 to 192. The total number of participants was 843 , with an age between five and 100 years, with elderly people ( $70-100$ years) being the most represented $(n=395)$. Three studies included only denture wearers [54,58,62], and one study involved schoolchildren [60].

The patients were from 10 countries: Brazil, China, Denmark, Finland, India, Italy, New Zealand, Sweden, and United Kingdom. Three studies were from Brazil [54,58,65].

The studies investigated a total of 16 strains (alone or in combination) of probiotics. The most represented were Lactobacillus spp., followed by Bifidobacterium spp., Saccaromyces spp., and in one case Propionibacterium spp., at doses from $5 \times 10^{5}$ to $5 \times 10^{9} \mathrm{CFU} / \mathrm{mL}$ one, two, or three times a day or less frequently (such as three times a week or every two weeks). None of the studies included prebiotics or synbiotics.

Most probiotics were given though lozenges or capsules, or with dairy products such as cheese, milk, or yogurt in some studies.

The length of the follow-up ranged from a minimum of four weeks to a maximum of 16 weeks.

The reported outcomes measures were different among studies. Three studies reported the means of CFU/mL, two studies reported the presence (yes/no) of Candida spp. carriage, and seven studies reported the Candida spp. carriage (yes/no) based on different thresholds of Candida spp. counts $\left(10^{2}\right.$, $10^{3}$, or $\left.10^{4}\right)$.

\subsection{Evaluation of the Risk of Bias for RCTs}

The results of the risk of bias evaluation are reported in Figure 2.
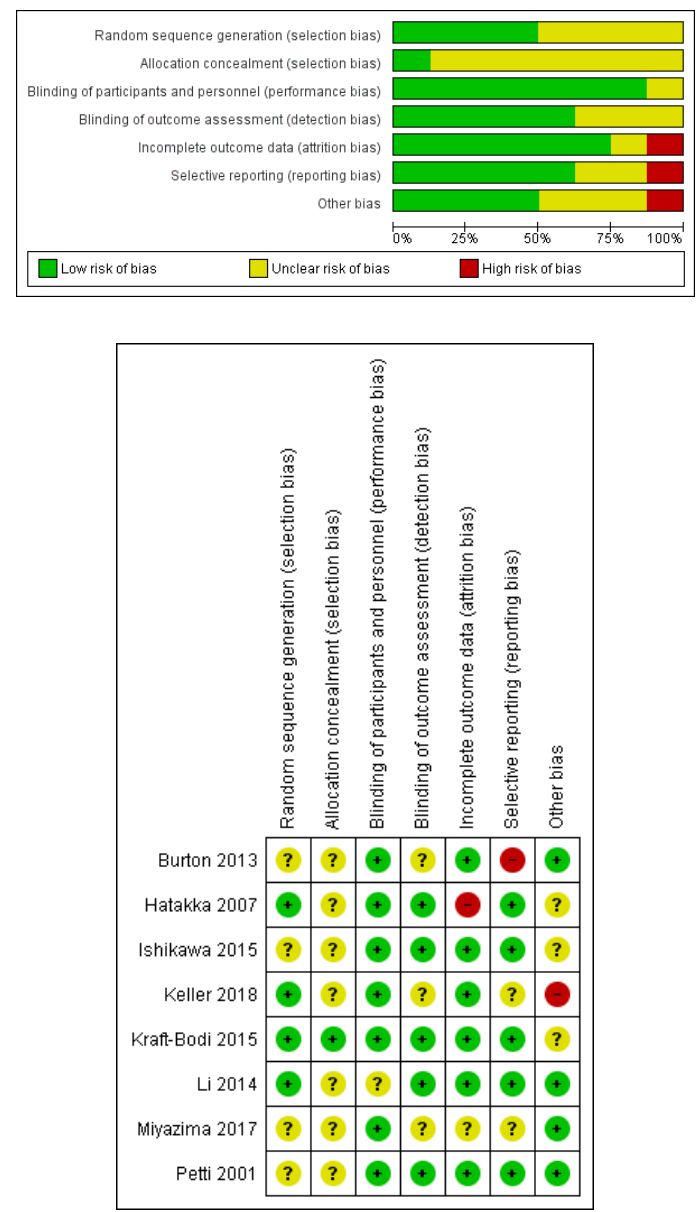

Figure 2. Risk of bias summary and graph. Green: low risk, yellow: unclear risk, red: high risk. 
In total, $50 \%$ of RCTs appropriately described the random sequence generation process, but only one reported the allocation concealment in detail. In most studies (87.5\%), participants and personnel were blinded; in five studies, the outcome assessors were also blinded. Six studies out of eight had a low risk of incomplete data, with only one (Hatakka et al. 2007 [53]) being classified as having a high risk because $30 \%$ of participants dropped out during the study. Regarding selective reporting, one study (Burton et al., 2003 [60]) was judged to have a high risk because, in the article, the outcome of interest was incompletely reported. However, after e-mail contact with the authors, the reviewers received the data required. Finally, the reviewers assigned high risk to Keller et al., 2018 [55], because, as declared by authors, "fewer participants completed the study as projected, and the study was terminated before completion because of recruitment problems".

\subsection{Evaluation of the Risk of Bias for Pre-Post Intervention Studies}

On the basis of the quality appraisal criteria proposed by the NHLBI [68] for pre-post intervention studies with no control group, the study by Lopez et al. (2018) [64] was classified as having poor quality because the paper consisted of a correspondence letter which provided poor information about the trial. The other three studies were susceptible to some bias, but not sufficient to invalidate the results (Figure 3). Thus, they were assigned to the fair quality category.

\begin{tabular}{|c|c|c|c|c|}
\hline Quality appraisal criteria & Lopez 2018 [65] & $\begin{array}{l}\text { Mendonça } 2012 \\
\text { [66] }\end{array}$ & $\begin{array}{l}\text { Rane } 2018 \\
\text { [63] }\end{array}$ & $\begin{array}{l}\text { Sutula } \\
2013[64]\end{array}$ \\
\hline $\begin{array}{l}\text { 1. Was the study question or objective clearly } \\
\text { stated? }\end{array}$ & Yes & Yes & Yes & Yes \\
\hline $\begin{array}{l}\text { 2. Were eligibility/selection criteria for the study } \\
\text { population prespecified and clearly described? }\end{array}$ & Not reported & Yes & Yes & Yes \\
\hline $\begin{array}{l}\text { 3. Were the participants in the study } \\
\text { representative of those who would be eligible } \\
\text { for the test/service/intervention in the general or } \\
\text { clinical population of interest? }\end{array}$ & Not reported & No & No & No \\
\hline $\begin{array}{l}\text { 4. Were all eligible participants that met the } \\
\text { prespecified entry criteria enrolled? }\end{array}$ & Not reported & No & Yes & $\begin{array}{l}\text { Cannot } \\
\text { determine }\end{array}$ \\
\hline $\begin{array}{l}\text { 5. Was the sample size sufficiently large to } \\
\text { provide confidence in the findings? }\end{array}$ & Not reported & Yes & $\begin{array}{l}\text { Not } \\
\text { reported }\end{array}$ & $\begin{array}{l}\text { Not } \\
\text { reported }\end{array}$ \\
\hline $\begin{array}{l}\text { 6. Was the test/service/intervention clearly } \\
\text { described and delivered consistently across the } \\
\text { study population? }\end{array}$ & Not reported & Yes & Yes & Yes \\
\hline $\begin{array}{l}\text { 7. Were the outcome measures prespecified, } \\
\text { clearly defined, valid, reliable, and assessed } \\
\text { consistently across all study participants? }\end{array}$ & No & Yes & Yes & Yes \\
\hline $\begin{array}{l}\text { 8. Were the people assessing the outcomes } \\
\text { blinded to the participants' } \\
\text { exposures/interventions? }\end{array}$ & Not reported & $\begin{array}{l}\text { Cannot } \\
\text { determine }\end{array}$ & $\begin{array}{l}\text { Cannot } \\
\text { determine }\end{array}$ & $\begin{array}{l}\text { Not } \\
\text { reported }\end{array}$ \\
\hline $\begin{array}{l}\text { 9. Was the loss to follow-up after baseline } 20 \% \\
\text { or less? Were those lost to follow-up accounted } \\
\text { for in the analysis? }\end{array}$ & Yes & Yes & Yes & Yes \\
\hline $\begin{array}{l}\text { 10. Did the statistical methods examine changes } \\
\text { in outcome measures from before to after the } \\
\text { intervention? Were statistical tests done that } \\
\text { provided } p \text {-values for the pre-to-post changes? }\end{array}$ & Yes & Yes & Yes & Yes \\
\hline $\begin{array}{l}\text { 11. Were outcome measures of interest taken } \\
\text { multiple times before the intervention and } \\
\text { multiple times after the intervention (i.e., did } \\
\text { they use an interrupted time-series design)? }\end{array}$ & No & No & No & No \\
\hline $\begin{array}{l}\text { 12. If the intervention was conducted at a group } \\
\text { level (e.g., a whole hospital, a community, etc.), } \\
\text { did the statistical analysis take into account the } \\
\text { use of individual-level data to determine effects } \\
\text { at the group level? }\end{array}$ & Not applicable & Not applicable & $\begin{array}{l}\text { Not } \\
\text { applicable }\end{array}$ & $\begin{array}{l}\text { Not } \\
\text { applicable }\end{array}$ \\
\hline
\end{tabular}

Figure 3. Quality appraisal criteria for pre-post intervention studies. 


\subsection{Meta-Analysis Results}

The results of the Bayesian random-effects meta-analysis conducted on the 12 evaluated studies are reported in the Figure 4.

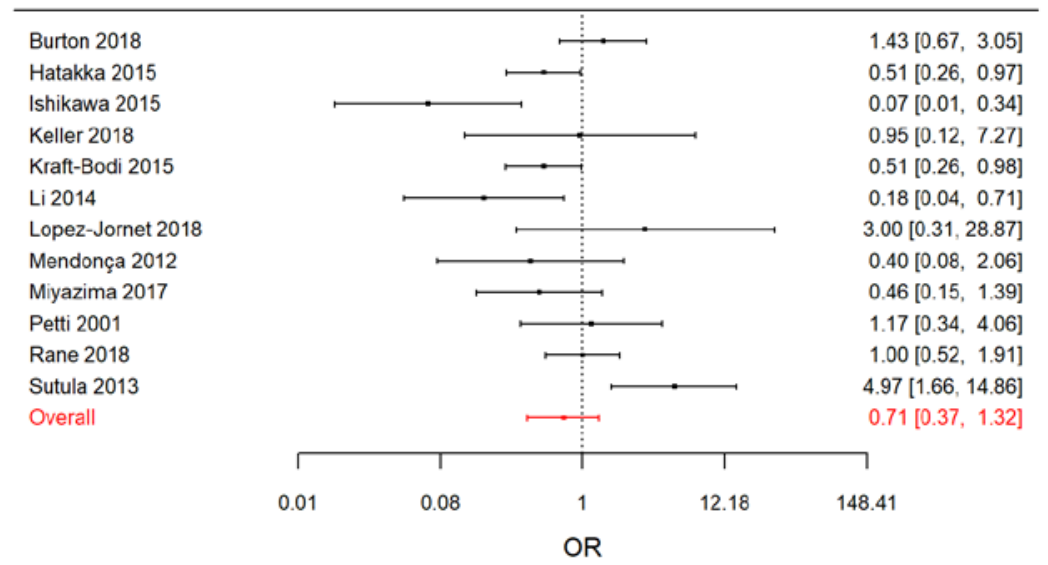

Figure 4. Forest plot from the Bayesian random-effects meta-analysis on all the selected studies.

Overall, we estimated that the OC odds ratio in the treated patients was around $30 \%$ lower than in the controls (OR $=0.71 ; 95 \% \mathrm{CrI}$ : 0.37, 1.32). However, it should be noted that the $95 \%$ confidence interval of the overall OR was not completely included in the beneficial effect region $(\mathrm{OR}<1)$. The $I^{2}$ index, with a posterior median of $56.3 \%$ (95\% CrI: $6.0 \%, 84.4 \%)$, suggests the presence of a relevant heterogeneity among studies.

When we restricted the meta-analysis to RCTs, a clear beneficial effect of treatment arose (Figure 5).

\begin{tabular}{|c|c|c|c|}
\hline Burton 2018 & & & $1.43[0.67,3.05]$ \\
\hline Hatakka 2015 & & & $0.51[0.26,0.97]$ \\
\hline Ishikawa 2015 & & & $0.07[0.01,0.34]$ \\
\hline Keller 2018 & & & $0.95[0.12,7.27]$ \\
\hline Kraft-Bodi 2015 & & & $0.51[0.26,0.98]$ \\
\hline Li 2014 & & & $0.18[0.04,0.71]$ \\
\hline Miyazima 2017 & & & $0.46[0.15,1.39]$ \\
\hline Petti 2001 & & & $1.17[0.34,4.06]$ \\
\hline \multirow[t]{4}{*}{ Overall } & & & $0.53[0.27,0.93]$ \\
\hline & $T$ & $T$ & 7 \\
\hline & 0.08 & 12.18 & 148.41 \\
\hline & \multicolumn{3}{|c|}{ OR } \\
\hline
\end{tabular}

Figure 5. Forest plot from the Bayesian random-effects meta-analysis on randomized controlled studies.

The estimated effect size was lower than in the previous analysis (OR $=0.53 ; 95 \% \mathrm{CrI}: 0.27,0.93$ ), but the precision of the estimate was larger. As expected, this subset of studies appeared to be less heterogeneous (posterior median of $I^{2}=32.2 \%$; $95 \mathrm{CrI}$ : $0.3 \%, 84.0 \%$ ), even if a relevant discrepancy between results was still present.

In a sensitivity analysis, we performed a stratified meta-analysis distinguishing between RCTs performed on denture wearers and RCTs on non-denture wearers. The effect of treatment appeared to be larger in denture wearers, with an OR equal to 0.65 (95\% CrI: 0.36, 1.17) for non-denture wearers (Figure 6) versus an OR equal to 0.19 (95\% CrI: 0.03, 1.29) for denture wearers. 


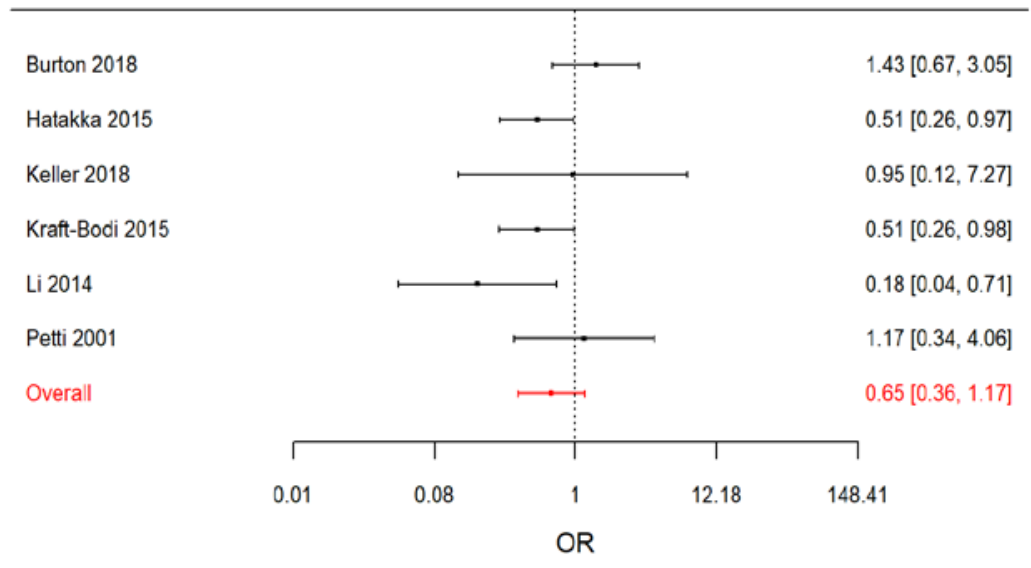

Figure 6. Forest plot from the Bayesian random-effects meta-analysis of the randomized controlled studies on non-denture wearers.

However, in interpreting this result, we should account for the fact that the meta-analysis on denture-wearing patients relied on only two studies.

When, in a second sensitivity analysis, we excluded from the RCTs the study by Burton et al. (2013) [60], which was conducted on schoolchildren, we observed a slight increase in effect size $(\mathrm{OR}=0.44 ; 95 \%$ CrI: $0.25,0.73)$ and a reduction in $I^{2}$ (posterior median of $I^{2}=7.0 \%$; $95 \%$ CrI: $0.2 \%$, $76.2 \%$ ) (Figure 7).

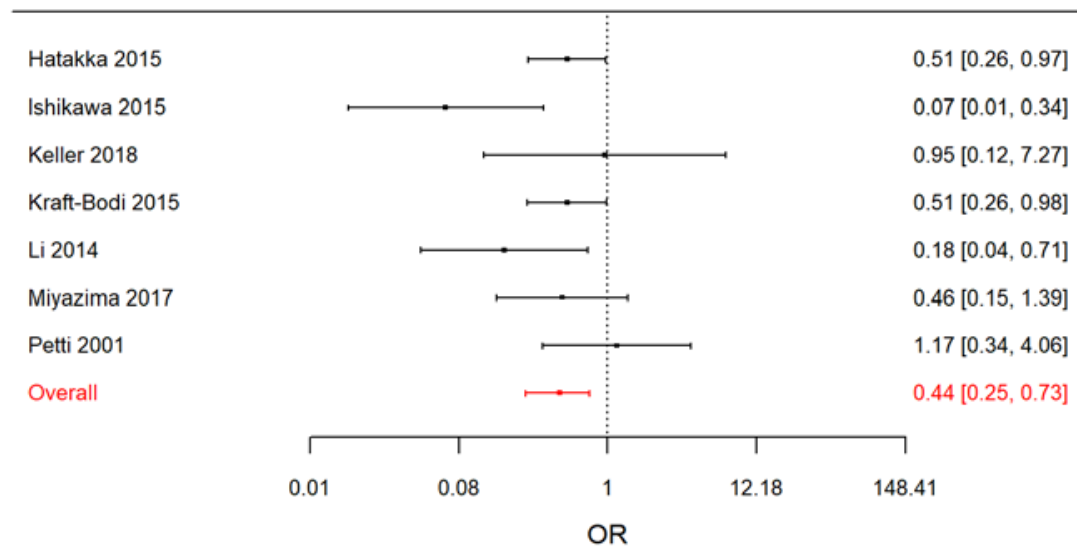

Figure 7. Forest plot from the Bayesian random-effects meta-analysis of the randomized controlled studies on adults.

A summary of the meta-analyses results is presented in Table 3.

Table 3. Summary of the results from the Bayesian random-effect meta-analyses. CrI—credibility interval.

\begin{tabular}{lcc}
\hline \multicolumn{1}{c}{ Type of Meta-Analysis } & $\begin{array}{c}\text { Meta-Analytic Estimate } \\
\text { (OR) (95\% CrI) }\end{array}$ & $\mathbf{I}^{\mathbf{2}} \mathbf{( 9 5 \%}$ CrI) \\
\hline All 12 studies & $0.71(0.37-1.32)$ & $56.3(6.0-84.4)$ \\
Only RCTs $_{\text {RCTs with non-denture wearers }}$ & $0.53(0.27-0.93)$ & $32.2(0.3-84.0)$ \\
RCTs with denture wearers $^{1}$ & $0.65(0.36-1.17)$ & $17.6(0.3-81.8)$ \\
RCTs with adult patients $^{\text {R }}$ & $0.19(0.03-1.29)$ & \\
\hline
\end{tabular}

\footnotetext{
${ }^{1}$ Results from the fixed-effects model.
} 
From the inspection of the funnel plot, no evidence of publication bias arose (Figure 8).

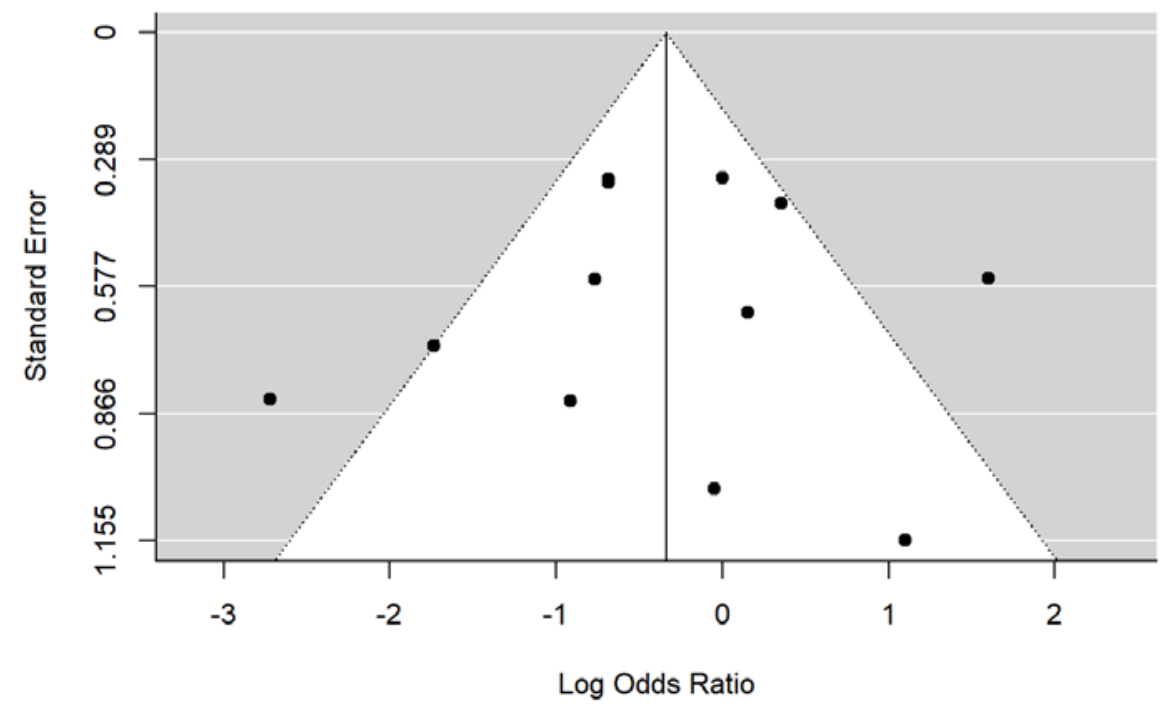

Figure 8. Funnel plot of publication bias.

These results were confirmed by the Begg's test ( $p=0.80$ for the meta-analysis on the RCTs, $p=1$ for the meta-analysis on the 12 studies).

\section{Discussion}

Currently, fungal infections are widespread, especially in developed countries. A higher incidence of Candida spp. infections is associated with some predisposing factors such as the use of dentures, malnutrition, endocrine disorders, smoke, and some chronic diseases such as diabetes, HIV infection, and cancer [75]. The anti-OC treatment is mainly based on antifungal drugs, but different clinical types of OCs and the increasing number of multi-resistance phenotypes of Candida spp. represent current threats for public health. Consequently, the development of alternative therapeutic or complementary measures appears necessary to prevent the emergence of fungal resistance [76].

Many studies demonstrated that probiotics represent an efficient alternative treatment against Candida spp. infections. Moreover, they are easy to use and, thus, these products are usually well accepted by the patients [77]. The present study provides an overview of the literature on this issue, as well as a quantitative analysis that combines the results of independent studies of different design.

Both the meta-analysis on the 12 selected studies and the meta-analysis conducted on the subset of the RCTs indicated that the treatment had a beneficial effect on reducing oral Candida spp. counts.

As expected, the heterogeneity among studies was relevant because we combined studies of different design, which focused on different populations, used different treatments and doses, and were affected by different kinds and levels of bias. Our sensitivity analyses highlighted that part of the observed heterogeneity could be due to an actual difference of the treatment effect when used in different populations. For example, we found that the effect on denture wearers was larger than the effect estimated on non-denture wearers. The result on denture wearers relied only on two RCTs and should be interpreted with caution, but it is suggestive of a true difference. The larger reduction in the number of Candida spp. colonies in these patients could be caused by the direct application of probiotic products on the denture surface [57]. This hypothesis supports the idea that a lower effect of probiotics could be due to the low frequency of usage, number of probiotic cells, and delivery system, which exert an effect on the period of probiotics maintenance at the oral cavity. In this sense, the development of a mucoadhesive buccal drug delivery system [78], in order to enable the prolonged retention at the site of action, could improve the therapeutic outcome. An indication in favor of the relevance of the number of doses per day seems to arise also from the comparisons of the ORs in our meta-analysis. 
If we focus on RCTs on non-denture wearers, a larger effect was reported in Li et al. (2014) [60], where the treated patients received three doses per day instead of one or two. Three doses were administered also in Keller et al. 2018 [55], but this study was affected by recruitment problems, and the result relied on a very small number of subjects.

A second relevant source of heterogeneity was related to the fact that different microbial probiotic strains could have different effects on the reduction of Candida spp. counts [58]. For example, Matsubara and colleagues found that, in a mice model, the treatment with Lactobacillus rhamnosus Lr-32 was more effective than the treatment with Lactobacillus acidophilus on the Candida spp. colonization levels [51]. Unfortunately, as the number of studies collected from the literature was too small to build a network of comparisons involving multiple treatments, we considered all treatments as having the same effect, which was clearly a very strong assumption.

Therefore, summarizing the obtained results, we can conclude that probiotics have a protective role in the Candida spp. infection and especially colonization. As previously reported, the anti-Candida properties can be explained in different ways, such as (a) through co-aggregation, modification of oral $\mathrm{pH}$, and production of $\mathrm{H}_{2} \mathrm{O}_{2}$ [45], (b) through releasing high amounts of lactic acid [47], and (c) through the complete inhibition of fungal biofilms $[48,49]$. However, these positive effects are highly linked to the administration method, the dosage, and the used probiotics strains. In addition, we did not find studies on prebiotics and synbiotics eligible for our meta-analysis. The effect of these products on the oral candidiasis must be better investigated in order to discover novel antifungal effects. In fact, some studies demonstrated that the combination of probiotics and prebiotics (synbiotics) can be very effective in infections $[79,80]$.

Our results suggest planning a new clinical study to evaluate the real effectiveness of probiotics treatment in Candida spp. infection. The focal points of the study should be (1) the age stratification of the patients (old or adult), (2) the administration method (topic or oral), the type (lozenges or capsules), the dosage, and the treatment duration, (3) the choice of appropriate probiotic strains (Lactobacillus spp., Bifidobacterium spp., Saccaromyces spp., or Propionibacterium spp.), and (4) the length of the patient follow-up.

Our study also had other limitations. Firstly, the number of studies included in the meta-analysis was small, in particular when we focused on the RCTs. Secondly, some of the studies had a high risk of bias. Thirdly, with the aim of providing an overview of the literature, we did not apply strong exclusion criteria, at the price of a larger heterogeneity among studies. For the same reason, we sometimes had to adopt approximations to obtain a common comparable effect measure (OR) from the results reported in the original papers; this could have introduced a certain degree of bias in the meta-analysis.

\section{Conclusions}

In conclusion, our meta-analysis is one of the first that critically evaluated the impact of probiotics in oral candidiasis and, on the basis of the meta-analysis results, despite the high heterogeneity among studies, we are confident in declaring that the treatment can have a beneficial effect on reducing oral Candida spp. counts.

Author Contributions: Conceptualization, T.M.; literature search, quality evaluation, data extraction: T.M., F.R.; data curation: T.M.; statistical analysis, T.M.; writing—original draft preparation, T.M., M.B., A.A.; writing—review and editing, T.M., M.B., A.A., B.B., F.R.; supervision of methods, M.B.; project administration, A.A.

Funding: This research received no external funding.

Conflicts of Interest: The authors declare no conflicts of interest.

PRISMA 2009 Checklist statement: The authors read the PRISMA 2009 Checklist, and the manuscript was prepared and revised according to the PRISMA 2009 Checklist. 


\section{References}

1. Sardi, J.; Scorzoni, L.; Bernardi, T.; Fusco-Almeida, A.; Mendes Giannini, M.J. Candida species: Current epidemiology, pathogenicity, biofilm formation, natural antifungal products and new therapeutic options. J. Med. Microbiol. 2013, 62, 10-24. [CrossRef]

2. Waggoner-Fountain, L.A.; Walker, M.W.; Hollis, R.J.; Pfaller, M.A.; Ferguson, J.E., 2nd; Wenzel, R.P.; Donowitz, L.G. Vertical and horizontal transmission of unique Candida species to premature newborns. Clin. Infect. Dis. 1996, 22, 803-808. [CrossRef] [PubMed]

3. Mayer, F.L.; Wilson, D.; Hube, B. Candida albicans pathogenicity mechanisms. Virulence J. 2013, 4, 119-128. [CrossRef] [PubMed]

4. Epstein, J.B.; Pearsall, N.N.; Truelove, E.L. Quantitative relationships between Candida albicans in saliva and the clinical status of human subjects. J. Clin. Microbiol. 1980, 12, 475-476. [PubMed]

5. Ghannoum, M.A.; Jurevic, R.J.; Mukherjee, P.K.; Cui, F.; Sikaroodi, M.; Naqvi, A.; Gillevet, P.M. Characterization of the oral fungal microbiome (mycobiome) in healthy individuals. PLoS Pathog. 2010, 6, e1000713. [CrossRef]

6. Fidel, P.L.; Vazquez, J.A.; Sobel, J.D. Candida glabrata: Review of epidemiology, pathogenesis, and clinical disease with comparison to C. albicans. Clin. Microbiol. Rev. 1999, 12, 80-96. [CrossRef]

7. Tintelnot, K.; Haase, G.; Seibold, M.; Bergmann, F.; Staemmler, M.; Franz, T.; Naumann, D. Evaluation of phenotypic markers for selection and identification of Candida dubliniensis. J. Clin. Microbiol. 2000, 38, 1599-1608.

8. Greenberg, M.S.; Glick, M.; Ship, J.A. Burket Oral Medicine, 11th ed.; BC Decker: Hamilton, ON, Canada, 2008; pp. 79-84.

9. Williams, D.; Lewis, M. Pathogenesis and treatment of oral candidosis. J. Oral Microbiol. 2011, $3,5771$. [CrossRef]

10. Webb, B.C.; Thomas, C.J.; Willcox, M.D.; Harty, D.W.; Knox, K.W. Candida-associated denture stomatitis. Aetiology and management: A review. Part 3. Treatment of oral candidosis. Aust. Dent. J. 1998, 43, 244-249. [CrossRef]

11. Portela, M.B.; Souza, I.P.R.; Abreu, C.M.; Bertolini, M.; Holandino, C.; Alviano, C.S.; Santos, A.L.S.; Soares, R.M.A. Effect of serine-type protease of Candida spp. isolated from linear gingival erythema of HIV-positive children: Critical factors in the colonization. J. Oral Pathol. Med. 2010, 39, 753-760.

12. Farah, C.S.; Lynch, N.; McCullough, M.J. Oral fungal infections: An update for the general practitioner. Aust. Dent. J. 2010, 55, 48-54. [CrossRef] [PubMed]

13. Akpan, A.; Morgan, R. Oral candidiasis. Postgrad. Med. J. 2002, 78, 455-459. [CrossRef] [PubMed]

14. Van Boven, J.F.; De Jong-van den Berg, L.T.W.; Vegter, S. Inhaled Corticosteroids and the Occurrence of Oral Candidiasis: A Prescription Sequence Symmetry Analysis. Drug Saf. 2013, 36, 231-236. [CrossRef] [PubMed]

15. Daya, A.M.; Anderson, I.; Portnof, J. Mandibular osteomyelitis associated with Candida albicans in marijuana and heroin abusers. Ann. Maxillofac. Surg. 2018, 8, 355. [CrossRef]

16. Keten, H.S.; Keten, D.; Ucer, H.; Yildirim, F.; Hakkoymaz, H.; Isik, O. Prevalence of oral Candida carriage and Candida species among cigarette and maras powder users. Int. J. Clin. Exp. Med. 2015, 8, 9847-9854.

17. Nishimaki, F.; Yamada, S.; Kawamoto, M.; Sakurai, A.; Hayashi, K.; Kurita, H. Relationship Between the Quantity of Oral Candida spp. and Systemic Condition/Diseases of the Host: Oral Candida Increases with Advancing Age and Anemia. Mycopathologia 2019. [CrossRef]

18. Santos, S.B.D.; Sabadin, C.E.S.; Mario, D.N.; Rigo, L.; Barbosa, D.A. Presence of Candida spp. and candidiasis in liver transplant patients. Anais Brasileiros de Dermatologia 2018, 93, 356-361.

19. Nadig, S.; Ashwathappa, D.; Manjunath, M.; Krishna, S.; Annaji, A.; Shivaprakash, P. A relationship between salivary flow rates and Candida counts in patients with xerostomia. J. Oral Maxillofac. Pathol. 2017, 21, 316. [CrossRef]

20. Mothibe, J.V.; Patel, M. Pathogenic characteristics of Candida albicans isolated from oral cavities of denture wearers and cancer patients wearing oral prostheses. Microb. Pathog. 2017, 110, 128-134. [CrossRef]

21. Lalla, R.V.; Patton, L.L.; Dongari-Bagtzoglou, A. Oral candidiasis: Pathogenesis, clinical presentation, diagnosis and treatment strategies. J. Calif. Dent. Assoc. 2013, 41, 263-268.

22. Al-Maskari, A.Y.; Al-Maskari, M.Y.; Al-Sudairy, S. Oral Manifestations and Complications of Diabetes Mellitus: A review. Sultan Qaboos Univ. Med. J. 2011, 11, 179-186. [PubMed] 
23. Mushi, M.F.; Bader, O.; Taverne-Ghadwal, L.; Bii, C.; Groß, U.; Mshana, S.E. Oral candidiasis among African human immunodeficiency virus-infected individuals: 10 years of systematic review and meta-analysis from sub-Saharan Africa. J. Oral Microbiol. 2017, 9, 1317579. [CrossRef] [PubMed]

24. Bett, J.V.S.; Batistella, E.Â.; Melo, G.; Munhoz, E.A.; Silva, C.A.B.; Guerra, E.N.D.S.; Porporatti, A.L.; De Luca Canto, G. Prevalence of oral mucosal disorders during pregnancy: A systematic review and meta-analysis. J. Oral. Pathol. Med. 2019, 48, 270-277. [CrossRef] [PubMed]

25. Russo, E.; Bacci, G.; Chiellini, C.; Fagorzi, C.; Niccolai, E.; Taddei, A.; Ricci, F.; Ringressi, M.N.; Borrelli, R.; Melli, F.; et al. Preliminary Comparison of Oral and Intestinal Human Microbiota in Patients with Colorectal Cancer: A Pilot Study. Front Microbiol. 2018, 8, 2699. [CrossRef]

26. Amedei, A.; Boem, F. I've Gut A Feeling: Microbiota Impacting the Conceptual and Experimental Perspectives of Personalized Medicine. Int. J. Mol. Sci. 2018, 19, 3756. [CrossRef]

27. Niccolai, E.; Boem, F.; Russo, E.; Amedei, A. The Gut-Brain Axis in the Neuropsychological Disease Model of Obesity: A Classical Movie Revised by the Emerging Director "Microbiome". Nutrients 2019, 11, 156. [CrossRef]

28. Milosevic, I.; Vujovic, A.; Barac, A.; Djelic, M.; Korac, M.; Spurnic, A.R.; Gmizic, I.; Stevanovic, O.; Djordjevic, V.; Lekic, N.; et al. Gut-Liver Axis, Gut Microbiota, and Its Modulation in the Management of Liver Diseases: A Review of the Literature. Int. J. Mol. Sci. 2019, 20, 395. [CrossRef]

29. De Almeida, C.V.; De Camargo, M.R.; Russo, E.; Amedei, A. Role of diet and gut microbiota on colorectal cancer immunomodulation. World J. Gastroenterol. 2019, 25, 151-162. [CrossRef]

30. Hill, C.; Guarner, F.; Reid, G.; Gibson, G.R.; Merenstein, D.J.; Pot, B.; Morelli, L.; Canani, R.B.; Flint, H.J.; Salminen, S.; et al. Expert consensus document. The International Scientific Association for Probiotics and Prebiotics consensus statement on the scope and appropriate use of the term probiotic. Nat. Rev. Gastroenterol. Hepatol. 2014, 11, 506-514. [CrossRef]

31. Guarner, F.; Sanders, M.E.; Eliakim, R.; Gangl, A.; Thomson, A.; Krabshuis, J.; Lemair, T.; Kaufmann, P.; de Paula, J.A.; Fedorak, R.; et al. World Gastroenterology Organisation; Global Guidelines Probiotics and Prebiotics. J. Clin. Gastroenterol. 2012, 46, 468-481. [CrossRef]

32. Fuller, R. Probiotics in human medicine. Gut 1991, 32, 439-442. [CrossRef] [PubMed]

33. Blaut, M. Relationship of prebiotics and food to intestinal microflora. Eur. J. Nutr. 2002, 41, i11-i16. [CrossRef] [PubMed]

34. Nagpal, R.; Wang, S.; Ahmadi, S.; Hayes, J.; Gagliano, J.; Subashchandrabose, S.; Kitzman, D.W.; Becton, T.; Read, R.; Yadav, H. Human-origin probiotic cocktail increases short-chain fatty acid production via modulation of mice and human gut microbiome. Sci. Rep. 2018, 8, 12649. [CrossRef] [PubMed]

35. Almeida, C.C.; Lorena, S.L.; Pavan, C.R.; Akasaka, H.M.; Mesquita, M.A. Beneficial effects of long-term consumption of a probiotic combination of Lactobacillus casei Shirota and Bifidobacterium breve Yakult may persist after suspension of therapy in lactose-intolerant patients. Nutr. Clin. Pract. 2012, 27, 247-251. [CrossRef] [PubMed]

36. LeBlanc, J.G.; Milani, C.; de Giori, G.S.; Sesma, F.; van Sinderen, D.; Ventura, M. Bacteria as vitamin suppliers to their host: A gut microbiota perspective. Curr. Opin. Biotechnol. 2013, 24, 160-168. [CrossRef] [PubMed]

37. Cho, Y.A.; Kim, J. Effect of Probiotics on Blood Lipid Concentrations: A Meta-Analysis of Randomized Controlled Trials. Medicine 2015, 94, 1714. [CrossRef]

38. Collado, M.C.; Jalonen, L.; Meriluoto, J.; Salminen, S. Protection mechanism of probiotic combination against human pathogens: In vitro adhesion to human intestinal mucus. Asia Pac. J. Clin. Nutr. 2006, 15, 570-575.

39. Oldak, A.; Zielinska, D. Bacteriocins from lactic acid bacteria as an alternative to antibiotics. Postepy higieny $i$ medycyny doswiadczalnej 2017, 71, 328-338.

40. Castagliuolo, I.; LaMont, J.T.; Nikulasson, S.T.; Pothoulakis, C. Saccharomyces boulardii protease inhibits Clostridium difficile toxin A effects in the rat ileum. Infect. Immun. 1996, 64, 5225-5232.

41. Guo, S.; Gillingham, T.; Guo, Y.; Meng, D.; Zhu, W.; Walker, W.A.; Ganguli, K. Secretions of Bifidobacterium infantis and Lactobacillus acidophilus Protect Intestinal Epithelial Barrier Function. J. Pediatr. Gastroenterol. Nutr. 2017, 64, 404-412. [CrossRef]

42. Maldonado Galdeano, C.; Cazorla, S.I.; Lemme Dumit, J.M.; Velez, E.; Perdigon, G. Beneficial Effects of Probiotic Consumption on the Immune System. Ann. Nutr. Metab. 2019, 74, 115-124. [CrossRef] [PubMed]

43. Wagner, R.D.; Pierson, C.; Warner, T.; Dohnalek, M.; Farmer, J.; Roberts, L.; Hilty, M.; Balish, E. Biotherapeutic effects of probiotic bacteria on candidiasis in immunodeficient mice. Infect. Immun. 1997, 65, 4165-4172. [PubMed] 
44. Sookkhee, S.; Chulasiri, M.; Prachyabrued, W. Lactic acid bacteria from healthy oral cavity of Thai volunteers: Inhibition of oral pathogens. J. Appl. Microbiol. 2001, 90, 172-179. [CrossRef] [PubMed]

45. Jørgensen, M.R.; Kragelund, C.; Jensen, P.Ø.; Keller, M.K.; Twetman, S. Probiotic Lactobacillus reuteri has antifungal effects on oral Candida species in vitro. J. Oral Microbiol. 2017, 9, 1274582. [CrossRef] [PubMed]

46. Coman, M.M.; Verdenelli, M.C.; Cecchini, C.; Silvi, S.; Orpianesi, C.; Boyko, N.; Cresci, A. In vitro evaluation of antimicrobial activity of Lactobacillus rhamnosus IMC 501(®), Lactobacillus paracasei IMC 502(®) and SYNBIO(®) against pathogens. J. Appl. Microbiol. 2014, 117, 518-527. [CrossRef] [PubMed]

47. Denkova, R.; Yanakieva, V.; Denkova, Z.; Nikolova, V.; Radeva, V. In vitro inhibitory activity of Bifidobacterium and lactobacillus strains against Candida Albicans. Bulg. J. Vet. Med. 2013, 16, 186-197.

48. Chew, S.Y.; Cheah, Y.K.; Seow, H.F.; Sandai, D.; Than, L.T.L. In vitro modulation of probiotic bacteria on the biofilm of Candida glabrata. Anaerobe 2015, 34, 132-138. [CrossRef]

49. Vilela, S.F.; Barbosa, J.O.; Rossoni, R.D.; Santos, J.D.; Prata, M.C.; Anbinder, A.L.; Jorge, A.O.; Junqueira, J.C. Lactobacillus acidophilus ATCC 4356 inhibits biofilm formation by C. albicans and attenuates the experimental candidiasis in Galleria mellonella. Virulence 2015, 6, 29-39.

50. Wannun, P.; Piwat, S.; Teanpaisan, R. Purification, Characterization, and Optimum Conditions of Fermencin SD11, a Bacteriocin Produced by Human Orally Lactobacillus fermentum SD11. Appl. Biochem. Biotechnol. 2016, 179, 572-582. [CrossRef]

51. Matsubara, V.H.; Silva, E.G.; Paula, C.R.; Ishikawa, K.H.; Nakamae, A.E. Treatment with probiotics in experimental oral colonization by Candida albicans in murine model (DBA/2). Oral Dis. 2012, 18, 260-264. [CrossRef]

52. Moher, D.; Liberati, A.; Tetzlaff, J.; Altman, D.G.; PRISMA Group. Preferred Reporting Items for Systematic Reviews and Meta-Analyses: The PRISMA Statement. PLoS Med. 2009, 6, e1000097. [CrossRef] [PubMed]

53. Hatakka, K.; Ahola, A.J.; Yli-Knuuttila, H.; Richardson, M.; Poussa, T.; Meurman, J.H.; Korpela, R. Probiotics reduce the prevalence of oral candida in the elderly-A randomized controlled trial. J. Dent. Res. 2007, 86, 125-130. [CrossRef] [PubMed]

54. Ishikawa, K.H.; Mayer, M.P.A.; Miyazima, T.Y.; Matsubara, V.H.; Silva, E.G.; Paula, C.R.; Campos, T.T.; Nakamae, A.E. A multispecies probiotic reduces oral Candida colonization in denture wearers. J. Prosthodont. 2015, 24, 194-199. [CrossRef] [PubMed]

55. Keller, M.K.; Kragelund, C. Randomized pilot study on probiotic effects on recurrent candidiasis in oral lichen planus patients. Oral Dis. 2018, 24, 1107-1114. [CrossRef]

56. Kraft-Bodi, E.; Jørgensen, M.R.; Keller, M.K.; Kragelund, C.; Twetman, S. Effect of Probiotic Bacteria on Oral Candida in Frail Elderly. J. Dent. Res. 2015, 94, 181S-186S. [CrossRef]

57. Li, D.; Li, Q.; Liu, C.; Lin, M.; Li, X.; Xiao, X.; Zhu, Z.; Gong, Q.; Zhou, H. Efficacy and safety of probiotics in the treatment of Candida-associated stomatitis. Mycoses 2014, 57, 141-146. [CrossRef]

58. Miyazima, T.Y.; Ishikawa, K.H.; Mayer, M.; Saad, S.; Nakamae, A. Cheese supplemented with probiotics reduced the Candida levels in denture wearers-RCT. Oral Dis. 2017, 23, 919-925. [CrossRef]

59. Petti, S.; Tarsitani, G.; D'Arca, A.S. A randomized clinical trial of the effect of yoghurt on the human salivary microflora. Arch. Oral Biol. 2001, 46, 705-712. [CrossRef]

60. Burton, J.P.; Drummond, B.K.; Chilcott, C.N.; Tagg, J.R.; Thomson, W.M.; Hale, J.D.; Wescombe, P.A. Influence of the probiotic Streptococcus salivarius strain M18 on indices of dental health in children: A randomized double-blind, placebo-controlled trial. J. Med. Microbiol. 2013, 62, 875-884. [CrossRef]

61. Da Costa, B.R.; Rutjes, A.W.S.; Johnston, B.C.; Reichenbach, S.; Nüesch, E.; Tonia, T.; Gemperli, A.; Guyatt, G.H.; Jüni, P. Methods to convert continuous outcomes into odds ratios of treatment response and numbers needed to treat: Meta-epidemiological study. Int. J. Epidemiol. 2012, 41, 1445-1459. [CrossRef]

62. Rane, D.J.; Nayakar, R.; Harakuni, S.; Patil, R. To evaluate the effect of probiotics on the prevalence of oral Candida organisms in denture wearers: An in vivo study. Indian J. Health Sci. Biomed. Res. 2018, 11, 136-145. [CrossRef]

63. Sutula, J.; Coulthwaite, L.A.; Thomas, L.V.; Verran, J. The effect of a commercial probiotic drink containing Lactobacillus casei strain Shirota on oral health in healthy dentate people. Microb. Ecol. Health Dis. 2013, 24. [CrossRef]

64. Lopez-Jornet, P.; Soler Tornero, C. Is Lactobacillus reuteri administration beneficial to oral candida levels? Int. J. Dermatol. 2018, 57, e5-e7. [CrossRef] [PubMed] 
65. Mendonça, F.H.; Santos, S.S.; Faria Ida, S.; Gonçalves e Silva, C.R.; Jorge, A.O.; Leão, M.V. Effects of probiotic bacteria on Candida presence and IgA anti-Candida in the oral cavity of elderly. Braz. Dent. J. 2012, 23, 534-538. [CrossRef]

66. Woolson, R.F.; Clarke, W.R. Mcnemar test. In Statistical Methods for the Analysis of Biomedical Data, 2nd ed.; Wiley: Hoboken, NJ, USA, 2011; p. 221.

67. Higgins, J.P.T.; Green, S. Cochrane Handbook for Systematic Reviews of Interventions; Version 5.1.0.; The Cochrane Collaboration, 2011; Available online: www.handbook.cochrane.org (accessed on 23 December 2018).

68. Study Quality Assessment Tools. Available online: https://www.nhlbi.nih.gov/health-topics/study-qualityassessment-tools (accessed on 3 January 2019).

69. Sutton, A.J.; Abrams, K.R. Bayesian Methods in Meta-Analysis and Evidence Synthesis. Stat. Methods Med. Res. 2001, 10, 277-303. [CrossRef]

70. Gelman, A.; Rubin, D.B. Inference from iterative simulation using multiple sequences. Stat. Sci. 1992, 7, 457-511. [CrossRef]

71. Egger, M.; Davey Smith, G.; Schneider, M.; Minder, C. Bias in meta-analysis detected by a simple, graphical test. BMJ 1997, 315, 629-634. [CrossRef]

72. Begg, C.B.; Mazumdar, M. Operating characteristics of a rank correlation test for publication bias. Biometrics 1994, 50, 1088-1101. [CrossRef]

73. R Core Team. R: A Language and Environment for Statistical Computing; R Foundation for Statistical Computing: Vienna, Austria, 2012; Available online: http://www.R-project.org/ (accessed on 03 January 2019).

74. Lunn, D.; Spiegelhalter, D.; Thomas, A.; Best, N. The BUGS project: Evolution, critique and future directions. Stat. Med. 2009, 28, 3049-3067. [CrossRef]

75. Rodloff, C.; Koch, D.; Schaumann, R. Epidemiology and antifungal resistance in invasive candidiasis. Eur. J. Med. Res. 2011, 16, 187-195. [CrossRef]

76. Dartevelle, P.; Ehlinger, C.; Zaet, A.; Boehler, C.; Rabineau, M.; Westermann, B.; Strub, J.M.; Cianferani, S.; Haïkel, Y.; Metz-Boutigue, M.H.; et al. D-Cateslytin: A new antifungal agent for the treatment of oral Candida albicans associated infections. Sci. Rep. 2018, 8, 9235. [CrossRef] [PubMed]

77. Taylor, R.S. Probiotics to prevent necrotizing enterocolitis: Too cheap and easy? Paediatr. Child. Health 2014, 19, 351-352. [CrossRef] [PubMed]

78. Shinkar, D.M.; Dhake, A.S.; Setty, C.M. Drug delivery from the oral cavity: A focus on mucoadhesive buccal drug delivery systems. PDA J. Pharm. Sci. Technol. 2012, 66, 466-500. [CrossRef] [PubMed]

79. Shimizu, K.; Yamada, T.; Ogura, H.; Mohri, T.; Kiguchi, T.; Fujimi, S.; Asahara, T.; Yamada, T.; Ojima, M.; Ikeda, M.; et al. Synbiotics modulate gut microbiota and reduce enteritis and ventilator-associated pneumonia in patients with sepsis: A randomized controlled trial. Crit. Care 2018, 27, 239. [CrossRef] [PubMed]

80. Chowdhury, A.H.; Adiamah, A.; Kushairi, A.; Varadhan, K.K.; Krznaric, Z.; Kulkarni, A.D.; Neal, K.R.; Lobo, D.N. Perioperative Probiotics or Synbiotics in Adults Undergoing Elective Abdominal Surgery: A Systematic Review and Meta-analysis of Randomized Controlled Trials. Ann. Surg. 2019. [CrossRef] [PubMed]

(C) 2019 by the authors. Licensee MDPI, Basel, Switzerland. This article is an open access article distributed under the terms and conditions of the Creative Commons Attribution (CC BY) license (http://creativecommons.org/licenses/by/4.0/). 